Dr. Dodd will go to Loods leaving an impressive record of achievement behind him in St. Andrews. The Gatty Marine Laboratory has been well and truly resuscitated in these pest thirteen years, during which time two major extensions have been built and a research tradition re-established. Dr. Dodd's main stream of research concerns the pituiterythyroid-gonad interrelations of cold-blooded vertebrates. He has published widely in this field and, supported financially by the Nuffield Foundation and by tho University, and scientifically by his wife, Dr. M. I. H. Dodd, who is also an endocrinologist, he has trained many research students while his own work has progressed. Dx. Dodd's appointment to the chair at Leeds is a timely and well-deserved recognition of his abilities as scientist and teacher. His colleagues at St. Andrews are well aware of their own loss, both personal and scientific, but their loss is Leeds' gain.

\section{U.S. National Academy of Sciences: Foreign Associates}

The following have been olected Foreign Associates of the U.S. National Acadomy of Sciences: Prof. E. A. Brun, professor of aeronautical engineering in the Ecole Nationale Supérieure de l'Aeronautique; Sir Cyril Hinshelwood, president of the Royal Society and professor of chemistry in the University of Oxford ; Dr. L. D. Landau, head of the Theoretical Section, Institute for Physical Problems of the Academy of Sciences of the U.S.S.R., and professor of physics in the University of Moseow; Prof. L. F. Leloir, research professor of biochemistry in the Facultad de Ciencias Exactas y Naturales, Univer. sity of Buenos Aires.

\section{Science and Technology in Africa South of the Sahara}

THE Scientific Secrotary to the Scientific Council for Africa South of the Sahara, Dr. E. T. Verdier, has pointed out that the reference to the Council in the recent article, "Scientific Research in the Overseas Territories of the British Commonwealth" (Nature, May 14, p. 501), does not make it clear that the members of the Council are chosen as representatives of a scientific discipline and that they are not responsible individually to the country from which they are drawn. Its constitution provides that "members of the Council shall be eminent scientists able, so far as possible, between them to speak with authority on all the main branchos of the sciences of direct interest to Africa South of the Sahara, regard also being paid to equitable representation of the geographical sub-divisions of Africa and of the countries and territories concerned". Further, "Vacancies on the Council shall be filled by the Council itself, subject to confirmation of its nominations by the participating Governments". The Council is thus a body of independent scientists whose primary allogiance is to the advancoment of science for the benefit of Africa, and as such it is well qualified to act as a counsellor to the member Governments of the Commission for Technical Co-operation in Africa South of the Sahara.

This Commission, as distinet from the Council, is an inter-governmental orgenization which includes to-day, besides the six original members (Belgium, France, Southern Rhodesia (now the Federation of Rhodesia and Nyasaland), Portugal, the Union of South Africa and the United Kingdom), the newly independent States of Ghana, Liberia, Guinea and the Cameroons. The Scientific Council/Commission is financed by the member Governments on a percentage basis, each in its own currency, the United Kingdom and France contributing the biggest percentage (just under 20) of the total cost in 1960 of about $£ 250,000$, which is distributed over some fifteen separate budgets. Dr. Verdier testifies that whatever else the Scientific Council has accomplished in the ten years of its existence, in spite of rapid changes in Africa, it still provides a common meeting place where representatives of its member Governments, whether scientists or not, can discuss technical matters of importance to the continent of Africa without being hampered by other considerations which often make international co-operation so difficult.

\section{The International Council of Scientific Unions}

THE Year Book of the International Council of Scientific Unions for 1960, besides a Calendar of Arrangements for 1960 , lists the staff of the Secretariat, members of the Bureau and the Executive Board, as well as the National and Scientific Members of the Council and the countries adhering to the Unions (Pp. 109. The Hague : Internationsl Council of Scientific Unions, 1960). Details are also given of the membership of the special committees, joint commission, and executive bodies of the permanent services of the International Council. With the statutes and by-laws of the Council, the rules and charters for the special committees and permanent services, the particulars of the commissions of the Unions, of the relations of the Council with the specialized agencies of the United Nations, the list of addresses of international organizations, and the alphabetical list of members of the joint commission and other organizations of the Council and of the officers of the Scientific Unions, the Year Book is a most useful reference work for scientists and others engaged in international scientific activities. The Treasurer's report and financial statement issued as a separate paper show an excess of income over expenditure for the year ended December 31, 1959, of 17,568 dollars (Pp. 12. The Hague: International Council of Scientifie Unions, 1960).

\section{Irrigation in Great Britain}

THE second report to the Central Advisory Water Committee of the Sub-committee on Growing Demand for Water must be one of the shortest official reports on record (Pp. 5. London: H.M. Stationery Office, 1960. 6d. net). Extending to two pages only, the first deals with the appointment and terms of reference of the sub-committee and explains that the document is an interim report on uncontrolled abstractions of surface water, with special reference to irrigation water for agriculture. The second page proposes the early introduction of a tomporary method of control through the river boards in view of the risk that growing abstractions will seriously deplete the natural flow of rivers at the time when they will bo at their lowest levels. A detailed report is promised at some future dato on the ultimate method of control, and this will doubtless reveal a selection of the data which has led to the early publication of the subcommitteo's conclusion. While the sub-committee also recognizes that ultimately "provision should be made for conservation and storage so that water would be available for all legitimate purposes", the urgency of this need is only being realized slowly in Great Britain. So far H.M. Central Advisory Water Committee has only been prepared to look forward 